\title{
Effect of Infrared Radiation on Healing of Diabetic Foot Ulcer
}

\author{
Amna Yehia Saad, Assistant Professor \\ Medical Surgical Nursing, Faculty of Nursing, Alexandria University, Egypt \\ Gehan Mohamed Desoky, Lecturer \\ Medical Surgical Nursing, Faculty of Nursing, Alexandria University, Egypt
}

\begin{abstract}
Diabetic foot ulcer is a worldwide health care problem affecting thousands of patients. If these ulcers left untreated, they can create severe complications. Objective: Evaluate the effect of infrared radiation on the healing of diabetic foot ulcer. Setting: The study was conducted at the outpatient clinics of vascular and diabetic foot of the Alexandria Main University Hospital. Subjects: They comprised a convenience sample of 50 patients with diabetic foot ulcer grade 1 and 2 (based on Wagner diabetic foot ulcer grade classification system). Patients were classified into the study and control groups ( $n=25$ in each group). Tools: Two tools were used for data collection. Tool 1: Diabetic foot ulcer patient's profile. Tool 2:Wound healing observation check list for patients with diabetic foot ulcers grade 1 and 2. Results: The results of the current study showed that there was a statistically significant difference in healing ulcers $(P<0.05)$ and mean healing time $(P<0.05)$ between the two groups. Conclusion: It was concluded that, infrared radiation therapy plus conventional dressing on diabetic foot ulcers grade 1 and 2, accelerates the ulcer healing, improves granulation tissue formation and diminishes wound exudation and inflammation. Recommendations: Infrared radiation therapy should be used in the diabetic outpatient clinics for patients with diabetic foot ulcers grade 1 and 2 .
\end{abstract}

Keywords: Infrared radiation; Wound healing; Diabetic foot ulcer.

\section{Introduction}

Diabetes mellitus is one of the biggest global health emergencies in the $21^{\text {st }}$ century, the prevalence of diabetes worldwide is estimated to be more than 371 million people ${ }^{(1)}$. In Egypt, diabetes is a major emerging clinical and public health problem. It is estimated that by the year 2045, nearly 8.2 million Egyptians (4.4 $9.4 \%$ ) of the population from 20 to 79 years of age will have diabetes ${ }^{(2)}$. The first world health organization's global report (2016) about diabetes, shows that the number of adults with diabetes, almost from 1980 to 2014 , has quadrupled. So that the number of people with diabetes increased from 108 million in 1980 to 422 million in $2014^{(3)}$. Every year more and more people live with this disease that results in many complications. Lower-limb complications of diabetes are common, particularly foot ulcers, and show a global increasing in annual incidence, prevalence and economic impact. These ulcers heal slowly and require intensive treatment. Patients with diabetes have a $12-25 \%$ risk of developing a foot ulcer, leading to more than 80,000 amputations, which are performed each year on diabetic patients in the United States ${ }^{(4,5)}$.

A diabetic foot ulcer is an open sore or wound that occurs in patients with diabetes, and is commonly located on the bottom of the foot ${ }^{(4)} .6 \%$ of patients have diabetic foot ulcer, hospitalized due to infection or other ulcer-related complication. Diabetic foot ulcers occurs due to a combination of factors, such as lack of feeling in the foot, poor circulation, foot deformities, irritation such as friction or pressure and trauma, as well as long duration of diabetes ${ }^{(6)}$.

People with diabetes often develop diabetic neuropathy due to several metabolic and neurovascular factors. Peripheral neuropathy causes loss of pain or 
feeling in the toes, feet, legs and arms due to distal nerve damage and low blood flow. Blisters and sores appear on numb areas of the feet and legs such as metatarsophalangeal joints and heel region, and as a result, pressure or injury goes unnoticed, so these areas become portal of entry for bacteria and infection ${ }^{(7)}$.

Diabetic ulcers can be classified on the basis of severity as mild (superficial and limited in size and depth), moderate (deeper or more extensive), or severe (accompanied by systemic signs or metabolic perturbations) or in grades using the Wagner diabetic foot ulcer grade classification system. Wagner classification grades the ulcer from grade 0 to grade 5 (grade $0=$ intact skin but foot at risk, grade $1=$ superficial ulceration and not infected, grade $2=$ deep ulceration with exposed tendons and joints with superficial infection, grade $3=$ deep ulceration and exposed bone with deep infection, grade $4=$ partial foot gangrene, grade 5=complete foot gangrene) ${ }^{(8)}$.

Today management of diabetic foot ulcer is a big challenge. The first objective in treating a diabetic foot ulcer is ulcer closure and helping accelerate healing process. There are various measures that have been used for the treatment (either intravenous laser therapy or noncontact heat therapy); one of the most effective treatments is temperature therapy using infrared radiation. It is one of the new noninvasive and safe treatments in caring of patients with diabetic foot ulcers ${ }^{(9-12)}$.

The infrared light therapy works in healing ulcer by many mechanisms, it increases circulation and the formation of new capillaries, helping the wound area to receive more of the oxygen and nutrients, initiate and maintain the healing process. It increases phagocytosis, to clean up the dead or damaged cells and dead bacteria, and helping in infection control. Also, it increases lymph system activity, to ensure efficient clean up and detoxification of the wounded area. Moreover, it stimulates the production of fibroblasts, which synthesizes collagen, elastin, and proteoglycans in the final healing phases, collagen is the key protein involved in wound closure. Finally it has a significant role in reduction of pain $^{(13-15)}$.

Nurses are responsible for patient's care. Wound care is the challenge for the nurses who care for them. So, this puts a burden on the nurse to update her knowledge about effectiveness of measures that accelerate the healing process as infrared radiation therapy, to provide optimum dressing, and giving attention to patients with diabetic foot ulcers. So, this study was done to evaluate the effect of infrared radiation on the healing of diabetic foot ulcer.

\section{Aim of the Study}

The aim of this study is to evaluate the effect of infrared radiation on the healing of diabetic foot ulcer.

\section{Research Hypothesis:}

The infrared radiation plus conventional dressing improve healing of diabetic foot ulcer.

\section{Materials and Method}

\section{Materials}

Design: The research design of this study was quasi experimental.

Setting: This study was conducted at the outpatient clinics of vascular and diabetic foot of the Alexandria Main University Hospital, to collect the necessary data.

Subjects: A convenience sample of 50 adult patients diagnosed with diabetic foot ulcers grade 1 and 2 (according to the Wagner diabetic foot ulcer grade classification system $)^{(8)}$. The study sample was estimated based on Epi info program, which used to estimate the sample size using the following parameters:

- Population size $=130$.

- $\quad$ Expected frequency $=50 \%$. 
- Margin of error $=10 \%$.

- Confidence coefficient $=95 \%$.

- $\quad$ Minimum sample size $=50$.

The patient's inclusion criteria were:

- Age between 20 - 60 years.

- Have a diabetic foot ulcer grade 1 or 2 (according to the Wagner diabetic foot ulcer grade classification system).

- Have no signs of ischemia around the ulcer, sepsis, and deep vein thrombosis or limb paralysis.

- Patients had diseases that can affect the healing process of ulcers like vascular diseases as lupus and rheumatoid arthritis were excluded from the study.

- Not on medication that might interfere with healing process as steroids, anti-inflammatory, antibiotics and chemotherapeutic drugs.

Every patient was assigned randomly into one of two groups (25 patients in each group). Group 1 was the control group and group 2 was the study group. Patients in the group 1 were subjected to conventional dressing, while patients in group 2 (study group) were subjected to the conventional dressing in addition to infrared radiation therapy.

\section{Tools:}

Tool I: Diabetic foot ulcer patient's profile

This tool was developed by the researcher after reviewing of literature ${ }^{(16,17)}$, to elicit patient's profile regarding diabetic foot ulcer. It comprised three parts to collect data concerning: Patient's sociodemographic characteristics, laboratory investigations and assessment of the affected limb.

Part 1: Patient's socio-demographic data: It included personal data as age, sex, marital status, level of education, onset and duration of ulcer formation, ulcer site and prescribed medication.

\section{Part 2: Laboratory investigations:}

Fasting blood sugar and CBCs.

\section{Part 3: Assessment of the affected limb (limbs):}

It included: Edema site, edema character, limb color when the feet dependent, elevated or in any position, skin hydration, temperature (using thermometer) and skin sensation, other skin lesions and limb pulsation.

Tool II: Wound healing observation check list for patients with diabetic foot ulcers grade 1 and 2

This tool was adapted from Yakout $\mathrm{R}$ $(2009)^{(18)}$, for initial assessment before dressing and 5 weeks follow up through ongoing documentation and evaluation of diabetic foot ulcer regarding the effect of dressing techniques and the extent of wound healing. It comprised three parts:

Part 1: For initial assessment of the morphological features of diabetic foot ulcer before dressing, and to observe and assess the diabetic foot ulcer after dressing throughout 5 weeks follow up.

(1) Size in centimeters: The linear dimensions of the wound surface are measured with measuring tape in centimeters.

(2) Depth: Observing the depth or thickness using the following score; $0=$ heeled, $1=$ superficial epithelization, $2=$ partial thickness skin loss that involves epidermis and/or dermis.

(3) Ulcer floor condition: This is indicated by percentage out of $100 \%$ as a total, and the findings were scored as follows:

a- Epithelial tissue (pink): $0=100 \%$ wound covered and surface intact, $1=75 \%$ to $<100 \%$ wound covered \&/or epithelial tissues extend $>0.5 \mathrm{~cm}$ into bed, $2=50 \%$ to $<75 \%$ wound covered \&/or epithelial tissues extend $<0.5 \mathrm{~cm}$ into bed, $3=25 \%$ to $<50 \%$ wound covered, $4=<25 \%$ wound covered. The total score of epithelial tissue $=10$ 
b-Granulation tissue (type and amount): $0=$ normal, $1=$ bright, beefy red, $75 \%-100 \%$ wound filled and/or tissues over growth, $2=$ bright, beefy red, $<75 \%$ and $>25 \%$ of wound filled, pink and/or dull, dusky red/ or fills $\leq 25 \%$ of wound, $4=$ no granulation tissue present. The total score of granulation tissue $=10$.

c-Area around the ulcer: was assessed and scored as follows:

Color: $0=$ pink or normal, $1=$ bright red and /or blanches to touch,

$2=$ white or grey pallor, $3=$ dark red or purple.

The total score of area color around the wound $=10$

$d$ - Edges were examined and assessed as follows: $0=$ flat or attached and no sides present, 1=Rolled under and thickened, 2=Hyper keratosis, 3=Hard and fibrous; callous like tissue formation around wound and at edges. The total score of ulcer edges $=6$.

e- Type of ulcer discharge or exudatesis observed and scored as follows: $0=$ none, $1=$ bloody: thin and bright red, $2=$ serosanguineous: thin and watery pale red to pink, $3=$ serous: thin, watery and clear, 4=Purulent: thin or thick, opaque tan to yellow. The total score of ulcer discharge $=10$.

f-Amount of ulcer discharge or exudates was assessed and scored as follows: $0=$ none: wound tissue dry, $1=$ Scant: wound tissue moist; no measurable exudates, 2=Small: wound tissue wet; drainage involves $\leq 5 \%$ of dressing, $3=$ Moderate: wound tissue saturated; drainage involves $>25 \%$ of dressing to $\leq 75 \%$ of dressing, $4=$ Profuse wound tissue bathed in fluid; drainage involves $>75 \%$ of dressing. The total score of amount of ulcer discharge $=10$.

g- Odor of discharge was assessed and scored as follows: $0=$ none and $1=$ foul.
Part 2: Extent of wound healing throughout 5 weeks follows up dressing evaluation period:

Wound healing indications: A scoring system was used to assess and evaluate the extent of ulcer healing; the wound healing varies from complete to partial healing or absence of healing. It consisted of $2=$ complete healing (complete epithelization of all foot ulcer), 1=partial healing (decrease of wound size and its depth without formation of scar tissue), $0=$ absence healing (no repaired of connective tissue and no decrease in wound size and depth) ${ }^{(18)}$.

Part 3: Photographic pictures were taken to document and compare different stages of wound healing.

\section{Method}

- An official letter from the Faculty of Nursing was submitted to the director of the chosen setting to obtain permission for data collection, after explanation of the aim of the study.

- Tool I was developed by the researcher after reviewing of the current related literature ${ }^{(16,17)}$, and tool II was adapted from Yakout R $(2009)^{(18)}$ and modifications were done accordingly.

- The study tools were revised by two experts in the field of diabetic foot ulcers and three experts in Medical Surgical Nursing, to test the tools for content validity, completeness and clarity of the items. Accordingly, the necessary modifications were carried out.

- Reliability of the tools was tested using Cronbach's Alpha where $\mathrm{r}=0.80$.

- A pilot study was initially carried out on 5 patients prior to the actual data collection, to assess clarity and applicability of the tools and to identify the difficulties that may be 
encountered during data collection. These patients were excluded from the study subjects.

- The study subjects meeting the inclusions criteria were assigned and divided into two equal groups (study and control group).

- The first group (control group) were received the conventional dressing.

- The second group (study group) were received the conventional dressing plus infrared radiation therapy.

- Photo for ulcer was taken at the initial assessment for patient who fulfilled the inclusion criteria, and the patients were assigned randomly into one of the two groups.

- An initial assessment of the patient's ulcer morphology was done at the dressing room in the outpatient of the main university hospital for every patient in both control and study groups, using tool I.

- Measurement of the actual size (measured with measuring tape in centimeters), depth of ulcer was done for every patient (both groups) in the initial assessment and every week (3 times/week) for a maximum period of 5 weeks, using the tool II.

- Dressing was done by the researcher for group one (control group) and group two (study group) using the conventional dressing method, the ulcer was washed with normal saline $(0.9 \%)$ solutions and after that, it was disinfected with betadine (10\%), then the skin around the ulcer washed with normal saline and disinfected with betadine solution.

- A sterile Vaselinsed piece of gauze was applied over the ulcer, and then a sterile piece of gauze or dressing was applied over the site of ulcer.

- Dressing was done three times/week for the patients and a photo was taken weekly for five weeks. All data were recorded in the patient's research sheet. Duration of dressing ranged between 15-20 minutes.

- Evaluation was done weekly (three times /week) for five weeks using tool II.

Infrared radiation plus conventional dressing Group 2"Study group ":

A conventional dressing was done according to the previous mentioned method. After application of sterile gauze, a powered infrared heat lamp 250 watt lamp tungsten generator was used 3 days a week for 5 weeks; a thermometer was placed on healthy skin around the ulcer to record temperature and ensure that its temperature has not exceeded $42^{\circ} \mathrm{C}$. The distance of infrared source from the skin was equal to $30 \mathrm{~cm}$ and was measured (using measuring tape in centimeters) between the lamp and ulcer, and the radiation duration was equal to 20 minutes. A radiation angle was selected perpendicular, so the maximum radiation absorption was gained then.

Patients were followed up and evaluated for 5 weeks (3 days a week). The ulcer was recorded as full recover, partial recovery and no recovery, using tool II.

\section{Ethical considerations:}

- Patient's written approval to participate was obtained, after explaining the purpose of the study.

- Privacy of the patients was maintained.

- Confidentiality of the collected data was secured.

- Patient's right to withdraw at any time of research participation was considered and respected.

\section{Statistical Analysis}

Statistical analysis was performed using Statistical Package for the Social Sciences 
Version 16.0 for windows (SPSS Inc. UK Ltd, Working). Continuous variables were described using means and standard deviation. Chi-square test and Fisher exact test were used to test the association between two qualitative variables or to detect the difference between two or more proportions. Monte Carlo for Chi square test for comparing between the two groups. The 0.05 level or below was used as the cutoff value for statistical significance.

\section{Results}

Table (1) presents Percentage distribution of patients in both control and study groups according to sociodemographic data. As regards age, the highest percentage of the sample from both groups aged between 40 and 50 years. Concerning marital status, the majority of the patients in both groups were married. This table also illustrates that $24 \%$ of the control and study groups had preparatory education. Also, this table shows that the majority of the patients in the control and study groups(76\%, 68\% respectively) were on insulin intake, more than one half of the patients in control and study groups (52\%, $60 \%$ respectively) had affected right foot, the onset of ulcer were occurred from (7-14) days. In addition, $48 \%$ of the patients from both groups, their fasting blood sugar level were between $120-180 \mathrm{mg} / \mathrm{dl}$.

Table (2) compares between the control and study groups according to initial assessment of the ulcer. The results indicate that callus tissue was found in $(72 \%)$ of the control group while present in $(76 \%)$ of the study group. Regarding sensitivity to touch, $(16 \%)$ of the patients in the control and study groups were sensitive to touch. Concerning loss of sensation, (52\%) of patient's ulcer in the control group had partial loss of sensation compared to (48\%) of the study group. Also, the majority of the patients in control and study groups (72\%, $84 \%$ respectively) had ulcer grade I.

Table (3) compares between the control and study groups according to size of ulcer in follow up period. Regarding to the length of ulcer, it was observed that the mean length of ulcer after one, five weeks was $(6.88 \pm 2.64,1.52 \pm 2.47$ respectively) in the control group, while the mean length of ulcer in the study group after one, five weeks was $(5.36 \pm 2.25, \quad 0.08 \pm 0.28$ respectively).

Concerning the width of the wound, the mean width of wound in the control group after one, five weeks was $(6.48 \pm 3.61$, $1.32 \pm 2.59$ respectively), while in the study group was $(4.08 \pm 1.91, \quad 0.08 \pm 0.28$ respectively). Also, a statistical significance differences were found between the two groups in length and width of ulcer in follow up period.

Table (4) compares between the control and study groups according to depth and epithelial tissue in follow up period. The results revealed a highly statistical significance difference between the two studied groups regarding depth and epithelial tissue in follow up period of wound healing as $(\mathrm{p}<0.001)$.

Table (5) illustrates Comparison between the control and study groups according to granulation tissue and ulcer edges. It was observed that the granulation tissue was seen normal in $48 \%$ of the control group after the fifth week, while it was normal in $92 \%$ of the study group after the same period.

Also, the results show that the ulcer edges was flat (attached) in $40 \%$ of the control group and in $100 \%$ of the study group after the fifth week, with a statistical significance difference between the two groups regarding the formation of granulation tissue and ulcer edges in all periods of ulcer healing as ( $\mathrm{p}$ value was $<0.001)$.

Table (6) illustrates comparison between the control and study groups according to ulcer discharge. It was noticed that, there was a statistical significance difference between the control and study groups regarding types of ulcer discharge or 
exudates and the amount of discharge as ( $p$ value $<0.001)$ in all periods of ulcer healing.

Table (7) shows comparison between the control and study groups according to odor, skin area around the ulcer and the ulcer characteristics. Regarding the odor of the ulcer, it was observed that $92 \%$ of patient in the control group had no ulcer odor after five weeks compared to $100 \%$ in the study group. Also, concerning the area around the wound, it was found that the skin area around the ulcer was pink or normal in $32 \%$ of the control group after the fifth week, while it was normal in $80 \%$ of the study group after the same period.

As regards the ulcer characteristics, it was intact and healthy in $56 \%$ of the control group after the fifth week, while it was intact in the $96 \%$ of the study group after the same period.

Also, the results revealed a highly statistical significance difference between the two groups after fifth week regarding skin area around the ulcer and ulcer characteristics as ( $\mathrm{p}$ value $=0.001)$.

Table (8) compares between the control and study groups according to extent of wound healing. The results revealed that $68 \%$ of the control group had partial healing of the wound, and $32 \%$ of them had complete healing, compared to $100 \%$ of patients in the study group had complete healing of ulcer, with a statistical significance difference between the two groups as ( $p$ value $<0.1000$ ).

\section{Discussion}

One of the most common and dangerous complications of diabetes is a foot ulcer. It leads to a considerable morbidity and costs on individuals and societies. Approximately 8.8 percent of hospital admissions of diabetic patients are for foot related problems, and these hospital admissions are about 13 days longer than for diabetics without foot related admissions. Approximately 15 percent of people with diabetes experience foot ulcers. And nearly 84 percent of lower limb amputations have a history of ulceration. Foot ulcers and amputations significantly reduce the quality of life. Management of patients with chronic conditions is still a matter of clinical experience than of evidenced based practice. It is often challenging for both patients and health care professional $^{(19-23)}$.

The current study shows a highly significant improvement in the size (length and width) of ulcer, in the study group compared to the control group, after one week therapy until five weeks. There was a dramatic reduction in ulcer size throughout the treatment sessions. This can be explained by; the application of infrared radiation therapy can improve tissue oxygenation, by improving microcirculation that increases blood supply to the ulcer tissue $^{(14)}$. This comes in agreement with Kajagar et al. (2012) ${ }^{(24)}$ they showed that diabetic ulcers were significantly reduced in size following 15 consecutive days of infrared laser therapy treatments, as compared to a control group.

One of the most important findings of the current study, is a significant improvement in the ulcer depth, epithelial and granulation tissue formation in the study group compared to control group throughout the study period, where in the study group nearly about one half of patients had superficial epithelialization after the second week, and the majority of patients had heeled ulcer after the fifth week. In relation to epithelial tissue, it was found that all patients in the study group had intact surface after the fifth week of heat therapy. Concerning granulation tissue, the majority of patients in the study group had granulation tissue formation after five weeks follow up. This could be interpreted by the fact that, local warming can increase blood flow and oxygen to the wound site, through dilating blood vessels, which can affect capacity of fibroblasts, leading to increase the synthesis of collagen fibers that enhance wound strength, and formation of 
granulation tissue, resulting in decreasing the depth of wound ${ }^{(25)}$.

These finding are in congruent with Kawalek et al. (2004) ${ }^{(26)}$ they reported that, a scoring rate in wound healing dependent on summation of scores of histological findings of epithelialization, granulation, cellular content, collagen deposition, and vascularity. A highly significant difference $\mathrm{P}<0.01$ in histological changes before and after irradiation of study group in comparison with standard medical therapy group. Another study by Whelan et al. (2003) $)^{(27)}$ showed that the infrared light is absorbed by some photoreceptors like hemoglobin, myoglobin, and cytochrome oxidase. The treatment effectively energized the cells by stimulating their cytochrome oxidase and triggering cellular and molecular events that have significant biological benefits in healing process. In contrast the results of Malm et al. $(2009)^{(28)}$, showed that there is no significant effect of infrared radiation on chronic wounds.

Excessive wound exudates can be a detrimental to wound healing, and the aim of ulcer care is to control the exudates, remove the slough and promote angiogenesis ${ }^{(29)}$. Ladwig et al. $(2002)^{(30)}$ suggested that exudates collected from wound fluid of chronic ulcers is associated with poor healing. The current study findings revealed that, a highly significant decrease in wound exudates (type and amount) among the study group, after 2 and 5 weeks follow up dressing period. At the end of the fifth week, all patients in the study group compared to about two third of patients in the control group had no wound exudates. This goes hand in hand with Alvarez (2003) $)^{(31)}$ who conducted a prospective study to compare diabetic foot ulcer healing, in patients being treated with noncontact heat therapy for 12 weeks, or until healing in patients with standard care (saline- moistened gauze). Evaluations were performed weekly for 12 weeks, the result showed that, the majority of the wounds in the heat therapy group were healed by full epithelialization, with absence of drainage compared to $40 \%$ in the standard group.
Concerning the skin area characteristics around the ulcer, it was observed that there was a highly statistically significant improvement in the study group than in the control group, in relation to pink or normal skin, healthy / intact skin, no tenderness, and no edema. This can be attributed to improvement of blood flow to the wound and area surrounding wound, due to vasodilation effect of heat therapy. This result is supported by Hopf $(2000)^{(32)}$ who found that application of noncontact radiant heat therapy has been shown to improve tissue oxygen blood supply to wound edges and surrounding skin around the ulcer.

The result of the current study showed that, all patients the in study group had complete healing after 5 weeks, compared to one third of patients in the control group. The simplest explanation of this result is that, local warming of the wound can increase local perfusion, support enzymatic reaction, and increase the availability of immune cells, thus lead to promotion and acceleration of wound healing ${ }^{(33)}$. This comes in line with Maiya $(2005)^{(34)}$ who reported that laser (radiation) can enhance tissue repair by releasing growth factors from fibroblasts and can accelerate the healing process of diabetic wounds.

The nurse has an important role in managing and caring for chronic wounds. So, she must be updating her knowledge about different modalities that promote wound healing. As shown from the results of this study, the infrared radiation therapy had a positive effect in accelerating wound healing in diabetic foot ulcer.

\section{Conclusion}

Infrared radiation therapy plus conventional dressing has a positive result on diabetic foot ulcers grade 1 and 2 , as it accelerates the ulcer healing, improves granulation tissue formation and diminishes wound exudation and inflammation.

\section{Recommendations}

- Infrared radiation therapy should be used in the diabetic outpatient clinics for patients with diabetic foot ulcers grade 1 and 2 . 
Table (1): Percentage distribution of patients in both control and study groups according to socio-demographic data

\begin{tabular}{|c|c|c|c|c|c|c|}
\hline \multirow{2}{*}{ Socio-demographic data } & \multicolumn{2}{|c|}{ Control group $(n=25)$} & \multicolumn{2}{|c|}{ Study group $(n=25)$} & \multirow{2}{*}{$\chi^{2}$} & \multirow{2}{*}{$\mathbf{P}$} \\
\hline & No. & $\%$ & No. & $\%$ & & \\
\hline \begin{tabular}{|r} 
Age \\
$20<30$ \\
$30<40$ \\
$40 \leq 50$ \\
\end{tabular} & $\begin{array}{c}0 \\
6 \\
19 \\
\end{array}$ & $\begin{array}{c}0.0 \\
24.0 \\
76.0 \\
\end{array}$ & $\begin{array}{c}0 \\
8 \\
17 \\
\end{array}$ & $\begin{array}{c}0.0 \\
32.0 \\
68.0 \\
\end{array}$ & 0.397 & 0.529 \\
\hline \begin{tabular}{|l} 
Sex \\
Male \\
Female \\
\end{tabular} & $\begin{array}{l}13 \\
12 \\
\end{array}$ & $\begin{array}{l}52.0 \\
48.0 \\
\end{array}$ & $\begin{array}{l}12 \\
13 \\
\end{array}$ & $\begin{array}{l}48.0 \\
52.0 \\
\end{array}$ & 1.882 & 0.574 \\
\hline \begin{tabular}{|l} 
Marital status \\
Single \\
Married \\
Divorced \\
Widow \\
\end{tabular} & $\begin{array}{c}2 \\
23 \\
0 \\
0\end{array}$ & $\begin{array}{c}8.0 \\
92.0 \\
0.0 \\
0.0\end{array}$ & $\begin{array}{c}2 \\
21 \\
0 \\
2\end{array}$ & $\begin{array}{c}8.0 \\
84.0 \\
0.0 \\
8.0\end{array}$ & 1.842 & ${ }^{M C} \mathrm{p}=0.543$ \\
\hline \begin{tabular}{|l} 
Level of education \\
Illiterate \\
Read and write \\
Primary \\
Preparatory \\
Secondary \\
University \\
\end{tabular} & $\begin{array}{l}2 \\
5 \\
4 \\
6 \\
5 \\
3 \\
\end{array}$ & $\begin{array}{c}8.0 \\
20.0 \\
16.0 \\
24.0 \\
20.0 \\
12.0 \\
\end{array}$ & $\begin{array}{l}4 \\
4 \\
4 \\
6 \\
5 \\
2\end{array}$ & $\begin{array}{l}16.0 \\
16.0 \\
16.0 \\
24.0 \\
20.0 \\
8.0 \\
\end{array}$ & 2.043 & ${ }^{M C} \mathrm{p}=0.652$ \\
\hline \begin{tabular}{|l} 
Occupation \\
Manual work \\
Clerk work \\
Not work \\
House wife \\
Retired
\end{tabular} & $\begin{array}{c}8 \\
10 \\
2 \\
2 \\
3\end{array}$ & $\begin{array}{c}32.0 \\
40.0 \\
8.0 \\
8.0 \\
12.0\end{array}$ & $\begin{array}{l}4 \\
14 \\
2 \\
2 \\
3\end{array}$ & $\begin{array}{c}16.0 \\
56.0 \\
8.0 \\
8.0 \\
12.0\end{array}$ & 2.885 & ${ }^{\mathrm{MC}} \mathrm{p}=0.438$ \\
\hline \begin{tabular}{|c} 
Residence \\
Urban \\
Rural
\end{tabular} & $\begin{array}{c}23 \\
2 \\
\end{array}$ & $\begin{array}{c}92.0 \\
8.0 \\
\end{array}$ & $\begin{array}{c}21 \\
4 \\
\end{array}$ & $\begin{array}{l}84.0 \\
16.0 \\
\end{array}$ & 0.758 & ${ }^{\mathrm{FE}} \mathrm{p}=0.667$ \\
\hline $\begin{array}{l}\text { Smoking habits } \\
\text { Yes } \\
\text { No }\end{array}$ & $\begin{array}{c}6 \\
19 \\
\end{array}$ & $\begin{array}{l}24.0 \\
76.0\end{array}$ & $\begin{array}{c}8 \\
17 \\
\end{array}$ & $\begin{array}{l}32.0 \\
68.0\end{array}$ & 3.742 & 0.235 \\
\hline $\begin{array}{c}\text { Insulin intake } \\
\text { Yes } \\
\text { No }\end{array}$ & $\begin{array}{c}19 \\
6 \\
\end{array}$ & $\begin{array}{l}76.0 \\
24.0\end{array}$ & $\begin{array}{c}17 \\
8 \\
\end{array}$ & $\begin{array}{l}68.0 \\
32.0\end{array}$ & 0.397 & 0.529 \\
\hline \begin{tabular}{|l|} 
Oral hypoglycemic \\
medication \\
Yes \\
No \\
\end{tabular} & $\begin{array}{c}19 \\
6 \\
\end{array}$ & $\begin{array}{l}76.0 \\
24.0 \\
\end{array}$ & $\begin{array}{c}16 \\
9 \\
\end{array}$ & $\begin{array}{l}64.0 \\
36.0 \\
\end{array}$ & 0.857 & 0.335 \\
\hline \begin{tabular}{|c} 
Onset of ulcer \\
1 day $<7$ days \\
7 days $<14$ days \\
14 days $<21$ days
\end{tabular} & $\begin{array}{c}4 \\
14 \\
7 \\
\end{array}$ & $\begin{array}{l}16.0 \\
56.0 \\
28.0\end{array}$ & $\begin{array}{c}4 \\
17 \\
4 \\
\end{array}$ & $\begin{array}{l}16.0 \\
68.0 \\
16.0\end{array}$ & 1.152 & ${ }^{\mathrm{MC}} \mathrm{p}=0.618$ \\
\hline \begin{tabular}{|} 
Affected foot \\
Right foot \\
Left foot
\end{tabular} & $\begin{array}{l}13 \\
12\end{array}$ & $\begin{array}{l}52.0 \\
48.0\end{array}$ & $\begin{array}{l}15 \\
10\end{array}$ & $\begin{array}{l}60.0 \\
40.0\end{array}$ & 0.325 & 0.569 \\
\hline \begin{tabular}{|} 
Fasting blood sugar level \\
Less than $80 \mathrm{mg} / \mathrm{dl}$ \\
$80-120 \mathrm{mg} / \mathrm{dl}$ \\
$120-180 \mathrm{mg} / \mathrm{dl}$ \\
More than $180 \mathrm{mg} / \mathrm{dl}$
\end{tabular} & $\begin{array}{c}0 \\
0 \\
12 \\
13\end{array}$ & $\begin{array}{c}0.0 \\
0.0 \\
48.0 \\
52.0\end{array}$ & $\begin{array}{c}0 \\
2 \\
12 \\
11\end{array}$ & $\begin{array}{c}0.0 \\
8.0 \\
48.0 \\
44.0\end{array}$ & 1.820 & ${ }^{\mathrm{MC}} \mathrm{p}=0.564$ \\
\hline
\end{tabular}

$\chi^{2}, \mathrm{p}: \chi^{2}$ and $\mathrm{p}$ values for Chi square test for comparing between the two groups

MCp: $\mathrm{p}$ value for Monte Carlo for Chi square test for comparing between the two groups

FEp: : p value for Fisher Exact for Chi square test for comparing between the two groups

*: Statistically significant at $\mathrm{p} \leq 0.05$ 
Table (2): Comparison between the control and study groups according to initial assessment of the ulcer

\begin{tabular}{|c|c|c|c|c|c|c|}
\hline \multirow[t]{2}{*}{ Initial assessment of the ulcer } & \multicolumn{2}{|c|}{$\begin{array}{c}\text { Control group } \\
(n=25)\end{array}$} & \multicolumn{2}{|c|}{$\begin{array}{c}\text { Study group } \\
(n=25)\end{array}$} & \multirow[t]{2}{*}{$\begin{array}{l}\text { Test of } \\
\text { sig. }\end{array}$} & \multirow[t]{2}{*}{$\mathbf{P}$} \\
\hline & No. & $\%$ & No. & $\%$ & & \\
\hline $\begin{array}{l}\text { Site } \\
\text { Plantar surface of } 1 \text { st toe } \\
\text { Plantar surface of } 1 \text { st metatarsal head } \\
\text { Plantar surface of } 5 \text { th toe } \\
\text { Sole } \\
\text { Heel } \\
\text { Other }\end{array}$ & $\begin{array}{l}5 \\
4 \\
4 \\
4 \\
2 \\
6\end{array}$ & $\begin{array}{c}20.0 \\
16.0 \\
16.0 \\
16.0 \\
8.0 \\
24.0\end{array}$ & $\begin{array}{l}4 \\
0 \\
4 \\
8 \\
6 \\
3\end{array}$ & $\begin{array}{l}16.0 \\
0.0 \\
16.0 \\
32.0 \\
24.0 \\
12.0\end{array}$ & $\chi^{2}=8.066$ & $\begin{array}{l}{ }^{M C} \mathrm{p}= \\
0.150\end{array}$ \\
\hline $\begin{array}{l}\text { Size } \\
\text { Min. - Max. } \\
\text { Mean } \pm \text { SD. }\end{array}$ & \multicolumn{2}{|c|}{$\begin{array}{c}2.0-15.0 \\
6.96 \pm 3.59\end{array}$} & \multicolumn{2}{|c|}{$\begin{array}{c}3.0-10.0 \\
5.76 \pm 2.13\end{array}$} & $\mathrm{t}=1.439$ & 0.158 \\
\hline $\begin{array}{l}\text { Affected foot when dependent } \\
\text { Normal or pink } \\
\text { Red } \\
\text { Blanched } \\
\text { Brown } \\
\text { Pale }\end{array}$ & $\begin{array}{l}2 \\
9 \\
6 \\
2 \\
6\end{array}$ & $\begin{array}{c}8.0 \\
36.0 \\
24.0 \\
8.0 \\
24.0\end{array}$ & $\begin{array}{c}4 \\
4 \\
12 \\
3 \\
2\end{array}$ & $\begin{array}{c}16.0 \\
16.0 \\
48.0 \\
12.0 \\
8.0\end{array}$ & $\chi^{2}=6.623$ & $\begin{array}{l}{ }^{\mathrm{MC}} \mathrm{p}= \\
0.167\end{array}$ \\
\hline $\begin{array}{l}\text { Affected foot when elevated } \\
\text { Normal or pink } \\
\text { Red } \\
\text { Blanched } \\
\text { Brown } \\
\text { Pale } \\
\end{array}$ & $\begin{array}{c}2 \\
14 \\
0 \\
2 \\
7\end{array}$ & $\begin{array}{c}8.0 \\
56.0 \\
0.0 \\
8.0 \\
28.0\end{array}$ & $\begin{array}{c}8 \\
12 \\
0 \\
2 \\
3 \\
\end{array}$ & $\begin{array}{c}32.0 \\
48.0 \\
0.0 \\
8.0 \\
12.0\end{array}$ & $\chi^{2}=5.310$ & $\begin{array}{l}{ }_{\mathrm{MC}}^{\mathrm{M}}= \\
0.144\end{array}$ \\
\hline $\begin{array}{l}\text { Affected foot in any position } \\
\text { Normal } \\
\text { Others } \\
\end{array}$ & $\begin{array}{l}14 \\
11 \\
\end{array}$ & $\begin{array}{l}56.0 \\
44.0 \\
\end{array}$ & $\begin{array}{l}14 \\
11 \\
\end{array}$ & $\begin{array}{l}56.0 \\
44.0 \\
\end{array}$ & $\chi^{2}=0.0$ & 1.000 \\
\hline \begin{tabular}{|c|} 
Callus tissue \\
Present \\
Absent \\
\end{tabular} & $\begin{array}{c}18 \\
7 \\
\end{array}$ & $\begin{array}{l}72.0 \\
28.0 \\
\end{array}$ & $\begin{array}{c}19 \\
6 \\
\end{array}$ & $\begin{array}{l}76.0 \\
24.0 \\
\end{array}$ & $\begin{array}{c}\chi^{2}= \\
11.538\end{array}$ & 0.066 \\
\hline \begin{tabular}{|c|} 
Fissure \\
Present \\
Absent \\
\end{tabular} & $\begin{array}{c}5 \\
20 \\
\end{array}$ & $\begin{array}{l}20.0 \\
80.0 \\
\end{array}$ & $\begin{array}{l}11 \\
14 \\
\end{array}$ & $\begin{array}{l}44.0 \\
56.0 \\
\end{array}$ & $\chi^{2}=3.309$ & 0.069 \\
\hline $\begin{array}{c}\text { Edema } \\
\text { Present } \\
\text { Absent } \\
\end{array}$ & $\begin{array}{c}19 \\
6 \\
\end{array}$ & $\begin{array}{l}76.0 \\
24.0 \\
\end{array}$ & $\begin{array}{c}17 \\
8 \\
\end{array}$ & $\begin{array}{l}68.0 \\
32.0 \\
\end{array}$ & $\chi^{2}=0.397$ & 0.529 \\
\hline $\begin{array}{l}\text { Character } \\
\text { Pitting } \\
\text { Non pitting } \\
\end{array}$ & $\begin{array}{c}11 \\
8 \\
\end{array}$ & $\begin{array}{l}57.9 \\
42.1 \\
\end{array}$ & $\begin{array}{c}11 \\
6 \\
\end{array}$ & $\begin{array}{l}64.7 \\
35.3 \\
\end{array}$ & $\chi^{2}=0.175$ & 0.676 \\
\hline $\begin{array}{l}\text { Temperature } \\
\text { Normal or warm } \\
\text { Cold } \\
\end{array}$ & $\begin{array}{l}12 \\
13 \\
\end{array}$ & $\begin{array}{l}48.0 \\
52.0 \\
\end{array}$ & $\begin{array}{c}16 \\
9 \\
\end{array}$ & $\begin{array}{l}64.0 \\
36.0 \\
\end{array}$ & $\chi^{2}=1.299$ & 0.254 \\
\hline \begin{tabular}{|l} 
Sensitive \\
Touch \\
Partial loss of sensation \\
Complete loss of sensation \\
\end{tabular} & $\begin{array}{c}4 \\
13 \\
8 \\
\end{array}$ & $\begin{array}{l}16.0 \\
52.0 \\
32.0\end{array}$ & $\begin{array}{c}4 \\
12 \\
9 \\
\end{array}$ & $\begin{array}{l}16.0 \\
48.0 \\
36.0\end{array}$ & $\chi^{2}=0.089$ & 0.765 \\
\hline \begin{tabular}{|l|} 
DorsalisPedis \\
Present \\
Absent
\end{tabular} & $\begin{array}{l}14 \\
11\end{array}$ & $\begin{array}{l}56.0 \\
44.0\end{array}$ & $\begin{array}{l}15 \\
10\end{array}$ & $\begin{array}{l}60.0 \\
40.0\end{array}$ & $\chi^{2}=1.389$ & 0.239 \\
\hline $\begin{array}{c}\text { Ulcer grades } \\
\text { Grade } 1 \\
\text { Grade } 2 \\
\end{array}$ & $\begin{array}{c}18 \\
7 \\
\end{array}$ & $\begin{array}{l}72.0 \\
28.0 \\
\end{array}$ & $\begin{array}{c}21 \\
4 \\
\end{array}$ & $\begin{array}{l}84.0 \\
16.0 \\
\end{array}$ & $\chi^{2}=1.049$ & 0.306 \\
\hline
\end{tabular}

$\chi 2, p: \chi^{2}$ and $\mathrm{p}$ values for Chi square test for comparing between the two groups

MCp: $\mathrm{p}$ value for Monte Carlo for Chi square test for comparing between the two groups

*: Statistically significant at $\mathrm{p} \leq 0.05$ 
Table (3): Comparison between the control and study groups according to size of ulcer in follow up period

\begin{tabular}{|c|c|c|c|c|c||}
\hline Size & After 1 week & After 2 weeks & After 3 weeks & After 4 weeks & After 5 weeks \\
\hline $\begin{array}{c}\text { Length cm } \\
\text { Control group } \\
\text { Min. - Max. }\end{array}$ & $3.0-10.0$ & $3.0-10.0$ & $2.0-10.0$ & $1.0-10.0$ & $0.0-8.0$ \\
Mean \pm SD. & $6.88 \pm 2.64$ & $6.64 \pm 2.40$ & $5.52 \pm 2.58$ & $4.24 \pm 2.70$ & $1.52 \pm 2.47$ \\
\hline $\begin{array}{c}\text { Study group } \\
\text { Min. - Max. }\end{array}$ & $3.0-10.0$ & $2.0-9.0$ & $0.0-7.0$ & $0.0-6.0$ & $0.0-1.0$ \\
Mean \pm SD. & $5.36 \pm 2.25$ & $3.80 \pm 2.02$ & $2.04 \pm 2.01$ & $0.72 \pm 1.40$ & $0.08 \pm 0.28$ \\
\hline T & $2.192^{*}$ & $4.531^{*}$ & $5.315^{*}$ & 5.792 & $2.899^{*}$ \\
\hline P & $0.033^{*}$ & $<0.001^{*}$ & $<0.001^{*}$ & $<0.001^{*}$ & $0.008^{*}$ \\
\hline $\begin{array}{c}\text { Width cm } \\
\text { Control group }\end{array}$ & & & & & \\
Min. - Max. & $3.0-15.0$ & $2.0-13.0$ & $2.0-10.0$ & $1.0-10.0$ & $0.0-9.0$ \\
Mean \pm SD. & $6.48 \pm 3.61$ & $5.92 \pm 3.32$ & $4.84 \pm 2.82$ & $3.44 \pm 2.92$ & $1.32 \pm 2.59$ \\
\hline Study group & & & & & \\
Min. - Max. & $2.0-10.0$ & $1.0-8.0$ & $0.0-7.0$ & $0.0-4.0$ & $0.0-1.0$ \\
Mean \pm SD. & $4.08 \pm 1.91$ & $2.08 \pm 1.71$ & $1.60 \pm 2.14$ & $0.48 \pm 0.96$ & $0.08 \pm 0.28$ \\
\hline T & $2.939^{*}$ & $4.183^{*}$ & $4.572^{*}$ & $4.819^{*}$ & $2.377^{*}$ \\
\hline P & $0.006^{*}$ & $<0.001^{*}$ & $<0.001^{*}$ & $<0.001^{*}$ & $0.026^{*}$ \\
\hline \hline
\end{tabular}

$\mathrm{t}, \mathrm{p}$ : $\mathrm{t}$ and $\mathrm{p}$ values for Paired $\mathrm{t}$-test for comparing between

*: Statistically significant at $\mathrm{p} \leq 0.05$ 
Table (4): Comparison between the control and study groups according to depth and epithelial tissue in each period

\begin{tabular}{|c|c|c|c|c|c|c|c|c|c|c|}
\hline \multirow[t]{2}{*}{ Depth and epithelial tissue } & \multicolumn{2}{|c|}{ After 1 week } & \multicolumn{2}{|c|}{$\begin{array}{l}\text { After } 2 \\
\text { Weeks }\end{array}$} & \multicolumn{2}{|c|}{$\begin{array}{r}\text { After } 3 \\
\text { weeks }\end{array}$} & \multicolumn{2}{|c|}{$\begin{array}{c}\text { After } 4 \\
\text { weeks }\end{array}$} & \multicolumn{2}{|c|}{$\begin{array}{c}\text { After } 5 \\
\text { weeks }\end{array}$} \\
\hline & No. & $\%$ & No. & $\%$ & No. & $\%$ & No. & $\%$ & No. & $\%$ \\
\hline \multicolumn{11}{|l|}{ Depth } \\
\hline \multicolumn{11}{|l|}{ Control group } \\
\hline Heeled & 0 & 0.0 & 0 & 0.0 & 0 & 0.0 & 0 & 0.0 & 12 & 48.0 \\
\hline Superficial epithelialization & 0 & 0.0 & 0 & 0.0 & 0 & 0.0 & 8 & 32.0 & 7 & 28.0 \\
\hline Partial thickness skin loss & 25 & 100.0 & 25 & 100.0 & 25 & 100.0 & 17 & 68.0 & 6 & 24.0 \\
\hline \multicolumn{11}{|l|}{ Study group } \\
\hline Heeled & 0 & 0.0 & 0 & 0.0 & 10 & 40.0 & 18 & 72.0 & 21 & 84.0 \\
\hline Superficial epithelialization & 0 & 0.0 & 12 & 48.0 & 10 & 40.0 & 7 & 28.0 & 4 & 16.0 \\
\hline Partial thickness skin loss & 25 & 100.0 & 13 & 52.0 & 5 & 20.0 & 0 & 0.0 & 0 & 0.0 \\
\hline$\chi^{2}$ & \multicolumn{2}{|c|}{-} & \multicolumn{2}{|c|}{$15.789^{*}$} & \multicolumn{2}{|c|}{$33.333^{*}$} & \multicolumn{2}{|c|}{$35.067^{*}$} & \multicolumn{2}{|c|}{$9.291^{*}$} \\
\hline$\tilde{P}$ & \multicolumn{2}{|c|}{-} & \multicolumn{2}{|c|}{$<0.001^{*}$} & \multicolumn{2}{|c|}{$<0.001^{*}$} & \multicolumn{2}{|c|}{$<0.001^{*}$} & \multicolumn{2}{|c|}{${ }^{\mathrm{MC}} \mathrm{p}=0.010^{*}$} \\
\hline \multicolumn{11}{|l|}{ Epithelial tissue } \\
\hline \multicolumn{11}{|l|}{ Control group } \\
\hline $\begin{array}{l}100 \% \text { wound covered and } \\
\text { surface intact }\end{array}$ & 0 & 0.0 & 0 & 0.0 & 0 & 0.0 & 0 & 0.0 & 14 & 56.0 \\
\hline $\begin{array}{l}75 \% \text { to }<100 \% \text { wound } \\
\text { covered } \& / \text { or epithelial tissues }\end{array}$ & 0 & 0.0 & 8 & 32.0 & 17 & 68.0 & 23 & 92.0 & 11 & 44.0 \\
\hline extend $>0.5 \mathrm{~cm}$ into bed. & 0 & 0.0 & & 32.0 & 17 & 00.0 & $2 J$ & 92.0 & & \\
\hline $\begin{array}{l}50 \% \text { to }<75 \% \text { wound covered } \\
\& / \text { or epithelial tissues extend }< \\
0.5 \mathrm{~cm} \text { into bed }\end{array}$ & 22 & 88.0 & 17 & 68.0 & 8 & 32.0 & 2 & 8.0 & 0 & 0.0 \\
\hline $25 \%$ to $<50 \%$ wound covered. & 2 & 8.0 & 0 & 0.0 & 0 & 0.0 & 0 & 0.0 & 0 & 0.0 \\
\hline$<25 \%$ wound covered. & 1 & 4.0 & 0 & 0.0 & 0 & 0.0 & 0 & 0.0 & 0 & 0.0 \\
\hline \multicolumn{11}{|l|}{ Study group } \\
\hline $\begin{array}{l}100 \% \text { wound covered and } \\
\text { surface intact }\end{array}$ & 0 & 0.0 & 0 & 0.0 & 10 & 40.0 & 18 & 72.0 & 25 & 100.0 \\
\hline $\begin{array}{l}75 \% \text { to }<100 \% \text { wound } \\
\text { covered \&/or epithelial tissues }\end{array}$ & 4 & 16.0 & 20 & 80.0 & 15 & 60.0 & 7 & 28.0 & 0 & 0.0 \\
\hline $\begin{array}{l}\text { extend }>0.5 \mathrm{~cm} \text { into bed. } \\
50 \% \text { to }<75 \% \text { wound covered }\end{array}$ & & & & & & & & & & \\
\hline $\begin{array}{l}\& / \text { or epithelial tissues extend < } \\
0.5 \mathrm{~cm} \text { into bed }\end{array}$ & 19 & 76.0 & 5 & 20.0 & 0 & 0.0 & 0 & 0.0 & 0 & 0.0 \\
\hline $25 \%$ to $<50 \%$ wound covered. & 1 & 4.0 & 0 & 0.0 & 0 & 0.0 & 0 & 0.0 & 0 & 0.0 \\
\hline$<25 \%$ wound covered. & 1 & 4.0 & 0 & 0.0 & 0 & 0.0 & 0 & 0.0 & 0 & 0.0 \\
\hline$\chi^{2}$ & \multicolumn{2}{|c|}{4.189} & \multicolumn{2}{|c|}{$11.688^{*}$} & \multicolumn{2}{|c|}{$19.795^{*}$} & \multicolumn{2}{|c|}{$31.912^{*}$} & \multicolumn{2}{|c|}{$18.103^{*}$} \\
\hline $\mathbf{P}$ & \multicolumn{2}{|c|}{${ }^{C} \mathrm{p}=0.159$} & \multicolumn{2}{|c|}{$0.001^{*}$} & ${ }^{\mathrm{MC}} \mathrm{p}<$ & $0.001^{*}$ & ${ }^{\mathrm{MC}} \mathrm{p}<$ & $.001^{*}$ & ${ }^{\mathrm{MC}} \mathrm{p}<$ & $.001^{*}$ \\
\hline
\end{tabular}

$\chi^{2}, \mathrm{p}: \chi^{2}$ and $\mathrm{p}$ values for Chi square test for comparing between the two groups

MCp: $\mathrm{p}$ value for Monte Carlo for Chi square test for comparing between the two groups

*: Statistically significant at $\mathrm{p} \leq 0.05$ 
Table (5): Comparison between the control and study groups according to granulation tissue and ulcer edges

\begin{tabular}{|c|c|c|c|c|c|c|c|c|c|c|}
\hline \multirow[t]{2}{*}{ Granulation tissue and ulcer edges } & \multicolumn{2}{|c|}{$\begin{array}{c}\text { Before } \\
\text { dressing } \\
\text { initial } \\
\text { assessment }\end{array}$} & \multicolumn{2}{|c|}{$\begin{array}{c}\text { After } 2 \\
\text { weeks }\end{array}$} & \multicolumn{2}{|c|}{$\begin{array}{l}\text { After } 3 \\
\text { weeks }\end{array}$} & \multicolumn{2}{|c|}{$\begin{array}{c}\text { After } 4 \\
\text { weeks }\end{array}$} & \multicolumn{2}{|c|}{$\begin{array}{l}\text { After } 5 \\
\text { weeks }\end{array}$} \\
\hline & No. & $\%$ & No. & $\%$ & No. & $\%$ & No. & $\%$ & No. & $\%$ \\
\hline \multicolumn{11}{|l|}{ Granulation Tissue } \\
\hline \multicolumn{11}{|l|}{ Control group } \\
\hline Normal & 0 & 0.0 & 0 & 0.0 & 0 & 0.0 & 0 & 0.0 & 12 & 48.0 \\
\hline $\begin{array}{l}\text { Bright beefy red } 75 \%-100 \% \text { wound } \\
\text { filled. }\end{array}$ & 0 & 0.0 & 0 & 0.0 & 2 & 8.0 & 6 & 24.0 & 11 & 44.0 \\
\hline $\begin{array}{l}\text { Bright beefy red }<75 \% \&>25 \% \\
\text { wound filled. }\end{array}$ & 0 & 0.0 & 4 & 16.0 & 8 & 32.0 & 15 & 60.0 & 2 & 8.0 \\
\hline $\begin{array}{l}\text { Pink or dull, dusky red } \leq 25 \% \text { wound } \\
\text { filled. }\end{array}$ & 4 & 16.0 & 13 & 52.0 & 15 & 60.0 & 4 & 16.0 & 0 & 0.0 \\
\hline No granulation tissue & 21 & 84.0 & 8 & 32.0 & 0 & 0.0 & 0 & 0.0 & 0 & 0.0 \\
\hline \multicolumn{11}{|l|}{ Study group } \\
\hline Normal & 0 & 0.0 & 0 & 0.0 & 8 & 32.0 & 18 & 72.0 & 23 & 92.0 \\
\hline $\begin{array}{l}\text { Bright beefy red } 75 \% \text { - } 100 \% \text { wound } \\
\text { filled. }\end{array}$ & 0 & 0.0 & 10 & 40.0 & 10 & 40.0 & 5 & 20.0 & 2 & 8.0 \\
\hline $\begin{array}{l}\text { Bright beefy red }<75 \% \text { \& }>25 \% \\
\text { wound filled. }\end{array}$ & 4 & 16.0 & 6 & 24.0 & 6 & 24.0 & 2 & 8.0 & 0 & 0.0 \\
\hline $\begin{array}{l}\text { Pink or dull, dusky red } \leq 25 \% \text { wound } \\
\text { filled. }\end{array}$ & 10 & 40.0 & 9 & 36.0 & 1 & 4.0 & 0 & 0.0 & 0 & 0.0 \\
\hline No granulation tissue & 11 & 44.0 & 0 & 0.0 & 0 & 0.0 & 0 & 0.0 & 0 & 0.0 \\
\hline$\chi^{2}$ & \multicolumn{2}{|c|}{$9.290^{*}$} & \multicolumn{2}{|c|}{$20.794^{*}$} & \multicolumn{2}{|c|}{$27.583^{*}$} & \multicolumn{2}{|c|}{$35.894^{*}$} & \multicolumn{2}{|c|}{$20.339^{*}$} \\
\hline${ }^{\mathrm{MC}} \mathbf{p}$ & \multicolumn{2}{|c|}{$0.006^{*}$} & \multicolumn{2}{|c|}{$<0.001^{*}$} & \multicolumn{2}{|c|}{$<0.001^{*}$} & \multicolumn{2}{|c|}{$<0.001^{*}$} & \multicolumn{2}{|c|}{$<0.001^{*}$} \\
\hline \multicolumn{11}{|l|}{ Ulcer edges } \\
\hline \multicolumn{11}{|l|}{ Control group } \\
\hline Flat (attached). & 0 & 0.0 & 0 & 0.0 & 0 & 0.0 & 0 & 0.0 & 10 & 40.0 \\
\hline Rolled under, thickened. & 0 & 0.0 & 0 & 0.0 & 6 & 24.0 & 19 & 76.0 & 13 & 52.0 \\
\hline Hyperkeratosis. & 2 & 8.0 & 8 & 32.0 & 19 & 76.0 & 6 & 24.0 & 2 & 8.0 \\
\hline Hard / fibrous & 23 & 92.0 & 17 & 68.0 & 0 & 0.0 & 0 & 0.0 & 0 & 0.0 \\
\hline \multicolumn{11}{|l|}{ Study group } \\
\hline Flat (attached). & 0 & 0.0 & 2 & 8.0 & 14 & 56.0 & 18 & 72.0 & 25 & 100.0 \\
\hline Rolled under, thickened. & 0 & 0.0 & 12 & 48.0 & 6 & 24.0 & 7 & 28.0 & 0 & 0.0 \\
\hline Hyperkeratosis. & 10 & 40.0 & 10 & 40.0 & 5 & 20.0 & 0 & 0.0 & 0 & 0.0 \\
\hline Hard / fibrous & 15 & 60.0 & 1 & 4.0 & 0 & 0.0 & 0 & 0.0 & 0 & 0.0 \\
\hline$\chi^{2}$ & \multicolumn{2}{|c|}{$7.018^{*}$} & \multicolumn{2}{|c|}{$31.386^{*}$} & \multicolumn{2}{|c|}{$22.167^{*}$} & \multicolumn{2}{|c|}{$33.216^{*}$} & \multicolumn{2}{|c|}{$23.080^{*}$} \\
\hline $\mathbf{P}$ & \multicolumn{2}{|c|}{$0.008^{*}$} & \multicolumn{2}{|c|}{${ }^{\mathrm{MC}} \mathrm{p}<0.001^{*}$} & $<0$. & $01^{*}$ & ${ }^{\mathrm{MC}} \mathrm{p}$ & $.001^{*}$ & ${ }^{\mathrm{MC}} \mathrm{p}<$ & $.001^{*}$ \\
\hline
\end{tabular}

$\chi^{2}$, $\mathrm{p}: \chi^{2}$ and $\mathrm{p}$ values for Chi square test for comparing between the two groups

MCp: $\mathrm{p}$ value for Monte Carlo for Chi square test for comparing between the two groups

*: Statistically significant at $\mathrm{p} \leq 0.05$ 
Table (6): Comparison between the control and study groups according to ulcer discharge

\begin{tabular}{|c|c|c|c|c|c|c|c|c|c|c|}
\hline \multirow[t]{2}{*}{ Ulcer discharge } & \multicolumn{2}{|c|}{$\begin{array}{c}\text { Before } \\
\text { dressing } \\
\text { initial } \\
\text { assessment }\end{array}$} & \multicolumn{2}{|c|}{ After 2 weeks } & \multicolumn{2}{|c|}{ After 3 weeks } & \multicolumn{2}{|c|}{ After 4 weeks } & \multicolumn{2}{|c|}{ After 5 weeks } \\
\hline & No. & $\%$ & No. & $\%$ & No. & $\%$ & No. & $\%$ & No. & $\%$ \\
\hline \multicolumn{11}{|c|}{$\begin{array}{l}\text { Type of ulcer discharge or } \\
\text { exudates }\end{array}$} \\
\hline \multicolumn{11}{|l|}{ Control group } \\
\hline None & 0 & 0.0 & 0 & 0.0 & 0 & 0.0 & 4 & 16.0 & 17 & 68.0 \\
\hline Bloody & 0 & 0.0 & 2 & 8.0 & 4 & 16.0 & 3 & 12.0 & 4 & 16.0 \\
\hline Serosanguineous & 4 & 16.0 & 2 & 8.0 & 7 & 28.0 & 10 & 40.0 & 2 & 8.0 \\
\hline Serous. & 1 & 4.0 & 7 & 28.0 & 6 & 24.0 & 6 & 24.0 & 2 & 8.0 \\
\hline Purulent & 20 & 80.0 & 14 & 56.0 & 8 & 32.0 & 2 & 8.0 & 0 & 0.0 \\
\hline \multicolumn{11}{|l|}{ Study group } \\
\hline None & 0 & 0.0 & 4 & 16.0 & 14 & 56.0 & 18 & 72.0 & 25 & 100.0 \\
\hline Bloody & 0 & 0.0 & 10 & 40.0 & 7 & 28.0 & 7 & 28.0 & 0 & 0.0 \\
\hline Serosanguineous & 10 & 40.0 & 5 & 20.0 & 2 & 8.0 & 0 & 0.0 & 0 & 0.0 \\
\hline Serous. & 0 & 0.0 & 4 & 16.0 & 2 & 8.0 & 0 & 0.0 & 0 & 0.0 \\
\hline Purulent & 15 & 60.0 & 2 & 8.0 & 0 & 0.0 & 0 & 0.0 & 0 & 0.0 \\
\hline$\chi^{2}$ & \multicolumn{2}{|c|}{4.135} & \multicolumn{2}{|c|}{$20.418^{*}$} & \multicolumn{2}{|c|}{$30.224^{*}$} & \multicolumn{2}{|c|}{$29.495^{*}$} & \multicolumn{2}{|c|}{$15.462^{*}$} \\
\hline${ }^{{ }^{M C}}$ p & \multicolumn{2}{|c|}{0.119} & \multicolumn{2}{|c|}{$<0.001^{*}$} & \multicolumn{2}{|c|}{$<0.001^{*}$} & \multicolumn{2}{|c|}{$<0.001^{*}$} & \multicolumn{2}{|c|}{$<0.001^{*}$} \\
\hline \multirow{2}{*}{\multicolumn{11}{|c|}{$\begin{array}{l}\text { Amount of ulcer } \\
\text { discharge } \\
\text { Control group }\end{array}$}} \\
\hline & & & & & & & & & & \\
\hline None & 0 & 0.0 & 0 & 0.0 & 0 & 0.0 & 2 & 8.0 & 16 & 64.0 \\
\hline Scant & 0 & 0.0 & 0 & 0.0 & 4 & 16.0 & 10 & 40.0 & 3 & 12.0 \\
\hline Small & 0 & 0.0 & 10 & 40.0 & 9 & 36.0 & 5 & 20.0 & 4 & 16.0 \\
\hline Moderate & 11 & 44.0 & 5 & 20.0 & 8 & 32.0 & 6 & 24.0 & 2 & 8.0 \\
\hline Profuse & 14 & 56.0 & 10 & 40.0 & 4 & 16.0 & 2 & 8.0 & 0 & 0.0 \\
\hline \multicolumn{11}{|l|}{ Study group } \\
\hline None & 0 & 0.0 & 2 & 8.0 & 12 & 48.0 & 18 & 72.0 & 25 & 100.0 \\
\hline Scant & 0 & 0.0 & 6 & 24.0 & 6 & 24.0 & 5 & 20.0 & 0 & 0.0 \\
\hline Small & 0 & 0.0 & 6 & 24.0 & 5 & 20.0 & 2 & 8.0 & 0 & 0.0 \\
\hline Moderate & 14 & 56.0 & 6 & 24.0 & 2 & 8.0 & 0 & 0.0 & 0 & 0.0 \\
\hline Profuse & 11 & 44.0 & 5 & 20.0 & 0 & 0.0 & 0 & 0.0 & 0 & 0.0 \\
\hline$\chi^{2}$ & \multicolumn{2}{|c|}{4.834} & \multicolumn{2}{|c|}{$23.333^{*}$} & \multicolumn{2}{|c|}{$21.143^{*}$} & \multicolumn{2}{|c|}{$24.314^{*}$} & \multicolumn{2}{|c|}{$16.889^{*}$} \\
\hline $\mathbf{P}$ & \multicolumn{2}{|c|}{${ }^{\mathrm{MC}} \mathrm{p}=0.107$} & \multicolumn{2}{|c|}{$<0.001^{*}$} & & $01^{*}$ & ${ }^{\mathrm{MC}} \mathrm{p}<$ & $001^{*}$ & ${ }^{\mathrm{MC}}{ }_{\mathrm{p}=}$ & $0.001^{*}$ \\
\hline
\end{tabular}

$\chi^{2}$, p: $\chi^{2}$ and $p$ values for Chi square test for comparing between the two groups

MCp: $\mathrm{p}$ value for Monte Carlo for Chi square test for comparing between the two groups

*: Statistically significant at $\mathrm{p} \leq 0.05$ 
Table (7): Comparison between the control and study groups according to odor, skin area around the ulcer and the ulcer characteristics

\begin{tabular}{|c|c|c|c|c|c|c|c|c|c|c|}
\hline \multirow[t]{2}{*}{\begin{tabular}{|c} 
Odor, skin area around \\
the ulcer and the ulcer \\
characteristics
\end{tabular}} & \multicolumn{2}{|c|}{\begin{tabular}{|c|} 
Before \\
dressing initial \\
assessment
\end{tabular}} & \multicolumn{2}{|c|}{ After 2 weeks } & \multicolumn{2}{|c|}{ After 3 weeks } & \multicolumn{2}{|c|}{ After 4 weeks } & \multicolumn{2}{|c|}{ After 5 weeks } \\
\hline & No. & $\%$ & No. & $\%$ & No. & $\%$ & No. & $\%$ & No. & $\%$ \\
\hline \multicolumn{11}{|l|}{ Odor } \\
\hline \multicolumn{11}{|l|}{ Control group } \\
\hline None & 2 & 8.0 & 6 & 24.0 & 13 & 52.0 & 21 & 84.0 & 23 & 92.0 \\
\hline Foul. & 23 & 92.0 & 19 & 76.0 & 12 & 48.0 & 4 & 16.0 & 2 & 8.0 \\
\hline Study group & & & & & & & & & & \\
\hline No & 4 & 16.0 & 15 & 60.0 & 25 & 100.0 & 25 & 100.0 & 25 & 100.0 \\
\hline Foul. & 21 & 84.0 & 10 & 40.0 & 0 & 0.0 & 0 & 0.0 & 0 & 0.0 \\
\hline$\chi^{2}$ & \multicolumn{2}{|c|}{6.921} & \multicolumn{2}{|c|}{$15.705^{*}$} & \multicolumn{2}{|c|}{$15.789^{*}$} & \multicolumn{2}{|c|}{4.348} & \multicolumn{2}{|c|}{2.083} \\
\hline $\mathbf{P}$ & \multicolumn{2}{|c|}{0.302} & \multicolumn{2}{|c|}{$<0.001^{*}$} & \multicolumn{2}{|c|}{$<0.001^{*}$} & \multicolumn{2}{|c|}{${ }^{\mathrm{FE}} \mathrm{p}=0.110$} & \multicolumn{2}{|c|}{$\mathrm{FE}_{\mathrm{p}}=0.490$} \\
\hline \multirow{2}{*}{\multicolumn{11}{|c|}{$\begin{array}{l}\text { Skin area around the } \\
\text { ulcer } \\
\text { Control group }\end{array}$}} \\
\hline & & & & & & & & & & \\
\hline Pink or normal & 0 & 0.0 & 0 & 0.0 & 0 & 0.0 & 0 & 0.0 & 8 & \\
\hline $\mathrm{Br}$ & 0 & 0.0 & 0 & 0.0 & 8 & 32.0 & 15 & 60.0 & 11 & 44.0 \\
\hline W & 10 & 40.0 & 19 & 76.0 & 13 & 52.0 & 8 & 32.0 & 6 & 24.0 \\
\hline Dark red or & 15 & 60.0 & 6 & 24.0 & 4 & 16.0 & 2 & 8.0 & 0 & 0.0 \\
\hline \multicolumn{11}{|l|}{ Study group } \\
\hline Pink or normal & 0 & 0.0 & 2 & 8.0 & 10 & 40.0 & 20 & 80.0 & 20 & 80.0 \\
\hline ht read. & 0 & 0.0 & 16 & 64.0 & 14 & 56.0 & 5 & 20.0 & 5 & 20.0 \\
\hline White & 9 & 36.0 & 1 & 4.0 & 1 & 4.0 & 0 & 0.0 & 0 & 0.0 \\
\hline Dark red or purple & 16 & 64.0 & 6 & 24.0 & 0 & 0.0 & 0 & 0.0 & 0 & 0.0 \\
\hline$\chi^{2}$ & \multicolumn{2}{|c|}{4.843} & \multicolumn{2}{|c|}{$30.807^{*}$} & \multicolumn{2}{|c|}{$27.451^{*}$} & & & & \\
\hline${ }^{N{ }^{N}}$ & & & & & & & & & & \\
\hline Characteristics & & & & & & & & & & \\
\hline Control group & & & & & & & & & & \\
\hline Healthy / Intact Skin & 0 & 0.0 & 0 & 0.0 & 0 & 0.0 & 0 & 0.0 & 14 & 56.0 \\
\hline Tenderness & 0 & 0.0 & 0 & 0.0 & 0 & 0.0 & 2 & 8.0 & 2 & 8.0 \\
\hline Dry & 0 & 0.0 & 0 & 0.0 & 4 & 16.0 & 4 & 16.0 & 0 & 0.0 \\
\hline welling) & 0 & 0.0 & 0 & 0.0 & 0 & 0.0 & 0 & 0.0 & 0 & 0.0 \\
\hline Edem & 0 & 0.0 & 0 & 0.0 & 0 & 0.0 & 0 & 0.0 & 0 & 0.0 \\
\hline More than one & 25 & 100.0 & 25 & 100.0 & 21 & 48.0 & 19 & 76.0 & 9 & 36.0 \\
\hline Study group & & & & & & & & & & \\
\hline Healthy / Intact Skin & 0 & 0.0 & 0 & 0.0 & 12 & 48.0 & 18 & 72.0 & 24 & 96.0 \\
\hline Tenderness & 0 & 0.0 & 6 & 24.0 & 2 & 8.0 & 2 & 8.0 & 1 & 4.0 \\
\hline Dry & 2 & 8.0 & 0 & 0.0 & 1 & 4.0 & 3 & 12.0 & 0 & 0.0 \\
\hline Sweeting (Swelling) & 0 & 0.0 & 0 & 0.0 & 0 & 0.0 & 0 & 0.0 & 0 & 0.0 \\
\hline Edema & 0 & 0.0 & 0 & 0.0 & 4 & 16.0 & 0 & 0.0 & 0 & 0.0 \\
\hline More than one & 23 & 92.0 & 19 & 76.0 & 6 & 24.0 & 2 & 8.0 & 0 & 0.0 \\
\hline$\chi^{2}$ & & & & & & & & & & \\
\hline $\mathbf{P}$ & ${ }^{\mathrm{FE}} \mathrm{p}=$ & .490 & $\mathrm{FE}_{\mathrm{p}}=$ & $.022^{*}$ & ${ }^{\mathrm{MC}} \mathrm{p}$ & $.001^{*}$ & ${ }^{M C} \mathrm{p}$ & $.001^{*}$ & & $.001^{*}$ \\
\hline
\end{tabular}

$\chi 2, \mathrm{p}: \chi^{2}$ and $\mathrm{p}$ values for Chi square test for comparing between the two groups

FEp: : $\mathrm{p}$ value for Fisher Exact for Chi square test for comparing between the two groups

MCp: $\mathrm{p}$ value for Monte Carlo for Chi square test for comparing between the two groups

*: Statistically significant at $\mathrm{p} \leq 0.05$ 
Table (8): Comparison between the control and study groups according to extent of wound healing

\begin{tabular}{|c|c|c|c|c|c|c|}
\hline \multirow[t]{2}{*}{ Extent of wound healing } & \multicolumn{2}{|c|}{$\begin{array}{l}\text { Control group } \\
\qquad(\mathbf{n}=\mathbf{2 5})\end{array}$} & \multicolumn{2}{|c|}{$\begin{array}{l}\text { Study group } \\
\qquad(n=25)\end{array}$} & \multirow[t]{2}{*}{$\chi^{2}$} & \multirow[t]{2}{*}{$\mathbf{P}$} \\
\hline & No. & $\%$ & No. & $\%$ & & \\
\hline Complete healing & 8 & 32.0 & 25 & 100.0 & & \\
\hline Partial healing. & 17 & 68.0 & 0 & 0.0 & & \\
\hline No healing. & 0 & 0.0 & 0 & 0.0 & & \\
\hline
\end{tabular}

$\chi 2, p: \chi^{2}$ and $\mathrm{p}$ values for Chi square test for comparing between the two groups

$*$ : Statistically significant at $p \leq 0.05$ 


\section{References}

1. Hakim A. Moghadam A, Shariati A, karimi H, Haghighizadeh M. Effect of infrared radiation on the healing of diabetic foot ulcer. International Journal of Endocrinology and Metabolism 2016; 14:3.

2. International Diabetes Federation 2017. Available at: https://twitter.com/IntDiabetesFed/status/20 17/943789141136953344.

3. WHO. Global report on diabetes. Geneva: World Health Organization; 2016.

4. International Diabetic Federation. Atlas: About 415 million adults worldwide have diabetes. 3. Brussels: IDF; 2015. Available at:

http://www.diabetesatlas.org/2015/contact. $\underline{\text { html. }}$

5. Houreld N. Shedding light on a new treatment for diabetic wound healing: A review on phototherapy. The Scientific World Journal 2014. Available at: http://dx.doi.org/10.1155/2014/398412.

6. Turns M. The diabetic foot: an overview of assessment and complications. Br $\mathrm{J}$ Nurs 2012; 20(15): 19-25.

7. Turns M. The diabetic foot: an overview for community nurses. $\mathrm{Br} \mathrm{J}$ Community Nurs 2012; 17(9): 424-27.

8. Lipsky A, Berendt R, Cornia B. "Infectious diseases society of America clinical practice guideline for the diagnosis and treatment of diabetic foot infections. Clinical Infectious Diseases 2012; 54(12): e132-e73.

9. Catherine N. A systematic review of lowlevel light therapy for treatment of diabetic foot ulcer. International $\mathrm{J}$ of tissue repair 2016; 24(2): 418-26.

10. Karim S, Ahmed E. Hyperbaric oxygen therapy versus monochromatic infrared therapy in the management of diabetic foot ulcer. Innovative Journal of Medical and Health Science 2013; 3(3): 67 - 70.

11. Schreml S, Szeimies M, Prantl L, Landthaler M, Babilas P. Wound healing in the $21^{\text {st }}$ century. J Am Acad Dermatol 2010;63(5): 866-81.
12. Zhang K. Red light therapy \& diabetic foot ulcers. 2017. Available at: https://www.linkedin.com.

13. James M. How to use red light therapy for wound healing at home. Jan 2017. Available at: http://www.infrared-lighttherapy.com/2017/red-light-therapy-wound.

14. Cohen J. 9 amazing effects of infrared light- with mechanisms and side effects. Infrared 2017. Available at: https://www.selfhacked.com/blog/infraredradiation-benefits/

15. Nethravathi V, Kshirsagar S, Kakade S. Effectiveness of infrared lamp therapy on healing of episiotomy wound among post natal mothers. Health science Journal 2015; 9(5): 3 .

16. Potter P, Perry A. Fundamentals of nursing. $5^{\text {th }}$ ed. Philadelphia: Mosby, 2001; 1593-96.

17. El Shatby A. Comparison between two dressing technique on the healing of grad 1 diabetic foot ulcers. Unpublished doctoral thesis. Faculty of Nursing, Alexandria University, 2003.

18. Yakout R. The effect of semiclosed compression technique as compared to contact heat therapy dressing on the healing of chronic venous leg ulcers. Unpublished doctoral thesis. Faculty of Nursing, Alexandria University, 2009.

19. Saar E, Lee H, Berlet C. The economic burden of diabetic foot and ankle disorders. Foot Ankle Int 2005; 26(1): 27-31.

20. Singh N, Armstrong G, Lipsky A. Preventing foot ulcers in patients with diabetes. JAMA 2005; 293(2):217-28.

21. Lee M, Chang C, Pan Y. Insufficient early detection of peripheral neurovasculopathy and associated factors in rural diabetes residents of Taiwan: a cross-sectional study. BMC Endocr Disord 2014; 14: 89.

22. Kumhar M, Saini T, Dara N. Foot wear and foot care knowledge - an independent risk factor for diabetic foot in Indian diabetics. Indian Medical Journal 2014; 148(1): 25-8. 
23. Gholap C, Mohite R. To assess the knowledge and practice regarding foot care among diabetes patients at Krishna Hospital, Karad. Indian J Sci Res 2013; 4(2): 69-75.

24. Kajagar M, Godhi S, Pandit A, Khatri S. Efficacy of low level laser therapy on wound healing in patients with chronic diabetic foot ulcers-a randomised control trial. Indian J Surg 2012; 74(5): 359-63.

25. Conutinho M. Red Light Therapy: Does Research Show Any Benefits? 2017. Available at: https://healthybutsmart.com/red-lighttherapy/

26. Kawalec S, Pfennigwerth C, Hethrington J. A Review of lasers in healing diabetic ulcers. The Foot 2004; 14: 68-71.

27. Whelan T, Buchmann V, Dhokalia A. Effect of NASA light- emitting diode irradiation on molecular changes for wound healing in diabetics. J Clin Laser MedSurg 2003; 21(2): 67-74.

28. Malm M, Lundeberg T. Effect of low power gallium arsenide laseron healing of venous ulcers. Scand J Plast Reconstr Surg Hand Surg 2009; 25(3):249-51.

29. Andros G, Armstrong D, Attinger C, Boulton A. Consensus statement on negative pressure wound therapy (V.A.C Therapy) for the management of diabetic food wound. OWM 2006; 1:32.
30. Ladwig G, Robson M, Liu R, Kuhn M. Ratios of activated matrix metalloproteinase-9 to tissue inhibitor of matrix metalloproteinase-1in wound fluids are inversely correlated with healing of pressure ulcer. Wound Repair Regen 2002; 10(1): 26-37.

31. Alvarez O, Rogers R, Booker J, Patel M. Effect of noncontact normothermic wound therapy on the healing of neuropathic (diabetic) foot ulcers: an interim analysis of 20 patients. J Foot Ankle Surg 2003; 42(1): $30-5$.

32. Hopf H. Role of warming and oxygen tension in wounds. International Congress and symposium Series 237. London: Royal Society of Medicine Press Ltd 2000:33-45.

33. Kahn F, Sookram C, Saraga F. Utilization of laser therapy in dermal ulceration secondary to diabetes mellitus. Diabetic Foot Canada 2015; 3: 26-30.

34. Maiya A, Kumar P, Rao L. Effect of low intensity helium-neon (He-Ne) laser irradiation on diabetic wound healing dynamics. J Photomed Laser Surg 2005; 23(2):187-90. 